stwo dzieci przy oddawaniu ich do szlooly, podjęte publicznie w kościele, było by na czasie.

Tak by przedstawiał się w najogólniejszym zarysie temat o wy, zyskaniu liturgii dla celów duszpasterskich. W praktyce będzie wymagało to od nas samych poważnego studium, aby się wżyé w modlitwę kościoła i starać się ją zrozumieć. Ksiądz, który zna dobrze mszał, powiedział biskup Dupanloup, nie będzie złym teologiem. Ale zarazem praca w tym kierunku będzie tą najbardziej kapłańską, tym duszpasterskim realizowaniem szczytnego hasła św. Benedykta: ,Nihil Operi Dei praeponatur".

S. p. Ks. Karol Csesznák.

\title{
ŚWIĘTO WNIEBOWZIĘCIA NAJŚWIĘTSZEJ MARII PANNY A SPRAWA DOGMATU MARIOLOGICZNEGO
}

Od czasu ogłoszenia dogmatu Niepokalanego Poczęcia Najśw. Marii Panny, a zwłaszcza od soboru watykańskiego, stała się aktualna w Kościele sprawa dogmatyzacji Wniebowzięcia, czyli uroczystej definicji, orzekającej, iż nauka o Wniebowzięciu Matki Bożej jest objawioną i stanowi przedmiot wiary. Owej dogmatyzacji zaczeto się zewsząd od Stolicy Apostolskiej coraz natarezywiej domagać. Rozwinął się w Kościele szeroko t. zw. ruch asumpcjonistyczny, mający niezmordowanych promotorów w osobach takich entuzjastów nowej definicji dogmatycznej, jak benedyktyni Vaccari i Renaudin, jezuita Salvador, księża Bartolo Longo, Crosta di Como i in. Z ogłoszonych niedawno dokumentów archiwalnych, dotyczących nowego ruchu ${ }^{1}$ ) wynika, iż w latach 1869 do 1941 nadeszły do Rzymu petycje w sprawie dogmatyzacji Wniebowzięcia od przeszło ośmiu milionów katolików z całego świata, a w tym od 113 kardynałów, 2505 arcybiskupów i biskupów: przeszło 32 tysięcy kapłanów świeckich i zakonników oraz około 51 tysięcy zakonnic.

A w związku z napływem do Stolicy Apostolskiej ze wszystkich stron świata próśb o orzeczenie dogmatyczne w sprawie Wniebowzięcia, rozwinęły się też gruntowniejsze studia naukowe w tym przedmiocie, których owocem jest niezliczona ilość rozpraw i artykułów, mnożących

1) Petitiones de Assumptione corporea B. V. Mariae in caelum definienda ad S. Sedem delatae, propositae... a Guilhelmo Hentrich et Rudolpho Gualtero de Moos. t. I-II, Città del Vaticano 1942. 
się jeszcze $z$ roku na rok. Teolodzy katoliccy badają mianowicie dokładnie nie tylko, czy nauka o Wniebowzięciu jest prawidziwą i pewną, lecz równiez, czy zawiera się ona w źródłach objawienia, względnie jak się tam za'wiera, aby móc dać uzasadnioną odpowiedź na pytanie, czy nauka ta nadaje się, względnie czy dojrzałą już jest do dogmatyzacji. Między innymi bada się pilnie dokumenty dotyczące początków, historii i liturgii święta Wniebowzięcia ${ }^{2}$ ). Wiadomo bowiem, że kult katolicki pozostaje w ścisłym związku z nauką i wiarą Kościoła, będąc praktycznym wyrazem tej wiary oraz nauki, według sławnego wskazania, przypisywanego pap. Celestynowi I, iż kult stanowi normę wierzenia $(,, \ldots u t$ legem credendi lex statuat supplicandi“").

Niejednolite są wnioski autorów katolickich, pozostające w związku z tą ostatnią kwestią święta i liturgii Wniebowzięcia. Niektórzy z nich, jak np. P. Renaudin ${ }^{3}$ ), utrzymują, że przez wprowadzenie i powszechne już od wieków obchodzenie święta sierpniowego nadaje Kościół nauce o cielesnym Wniebowzięciu Marii sankcję dogmatyczną tak, że naukę tę należy uważać nie tylko za pewną, ale również za dogmat wiary, czyli za prawdę objawioną przez Boga i jako taką podaną przez Kościół do wierzenia (w zwyczajnym, powszechnym nauczaniu). Natomiast inni, jak J. Ernst ${ }^{4}$ ), czy M. Jugie ${ }^{5}$ ), są zdania, że święto Wniebowzięcia nie dowodzi jeszcze samo prawdziwości faktu cielesnego Wniebowzięcia, a tym mniej pochodzenia nauki o takim Wniebowzięciu $\mathrm{z}$ objawienia bożego i należenia jej do dogmatów wiary.

Którzy mają słuszność? Aby rozstrzygnąć ową dosyć ważną dla aktualnej sprawy dogmatyzacji Wniebowzięcia kwestię, należy przede wszystkim rozpatrzyć dokładniej, jak przedstawia się historia i przedmiot święta sierpniowego. Czy mianowicie święto to, względnie jego liturgia, ma od początku i niezmiennie w ciągu wieków, jako swój wyraźnie sprecyzowany przedimiot, Wniebowzięcie Marii co do duszy i ciała zarazem, czy té̇ rzecz inaczej się przedstawia?

Otóż, jeśli chodzi najpierw o początek dzisiejszego święta Wniebowzięcia, to pewną jest rzeczą, iż wywodzi się ono, jako swego zawiązku,

2) Por. np.: B. Capelle, La fête de l'Assomption dans l'histoire liturgique, w Eph. Theol. Lovanienses, t. III (1926), str. 33-45; M. Jugie, La mort et l'assomption de la Sainte Vierge - étude historico-doctrinale. Città del Vaticano 1944, str. 172-212; $338-343 ; 424-430 ; 460-462 ; 518-525 ; 589-594 ; 618$ n.; O. Faller, De priorum saeculorum silentio circa assumptionem B. Mariae Virginis, Romae 1946, str. 18-26.

3) Por. „Assumptio B. Mariae Virginis Matris Dei“, Taurini - Romae 1933, str. $13 \mathrm{n}$.

4) Die leibliche Himmelfahrt Maria historisch-dogmatisch nach ihrer Definierbarkeit beleuchtet, Regensburg 1921, str. 35-43.

5) Por. dz. c. str. 58. 
z pierwszego i przez dłuższy czas jedynego święta maryjnego, które istniało w niektórych kościołach wschodnich i zachodnich ,może przy końcu IV wieku, a napewno przy końcu w. V-go" $\left.{ }^{6}\right)$. Pierwotne to święto nosiło miano „Pamiątka Bożej Rodzicielki“, wzgl. „Pamiątka świętej Marii“, a obchodzone było w grudniu luł w styczniu, w łączności z tajemnicą Bożego Narodzenia. Za przedmiot zaś miało przywilej Bożego Macierzyństwa Najśw. Marii Panny.

W drugiej połowie VI w. przekształca się na Wschodzie dość powszechnie owa pierwotna uroczystość „Pamiątki Bożej Rodzicielki“ w święto „Zaśnięcia“ (kojmesis), względnie „Odejścia“ (metastasis, metathesis, metabasis) Marii $\left.{ }^{7}\right)$, a cesarz Maurycjusz (582-602) naznacza, jako termin tego święta, dzień 15 sierpnia. Zgodnie z nową nazwą święta, występuje w jego liturgii nowy bezpośredni przedmiot. Jest nim mianowicie śmierć Marii, wzgl. odejście Jej przez śmierć do nieba. W homiliach Ojców wschodnich na ową uroczystość, pochodzących z w . VIII i następnych występują, obok uwag o śmierci Marii, wyraźne wzmianki już to o cielesnym Jej Wniebowzięciu, już też niekiedy (zwłaszcza w w. IX) o przeniesieniu zachowanego od zepsucia ciała Matki Bożej do raju, czy też jakiegoś nieznanego miejsca, gdzie oczekuje na powszechne zmartwychwstanie.

Ze Wschodu przeszczepiono w VII w. nowe święto na Zachód, najpierw do kościoła rzymskiego (może za sprawą pap. Sergiusza I, który pochodził z Syrii i obeznany był z liturgią wschodnią), a następnie do kościołów angielskich, francuskich, hiszpańskich i in. Nosiło ono tu najpierw tytuły oznaczające świętą śmierć Marii, wgzl. przejście do nieba, czy narodziny dla nieba: „Dormitio", „Depositio", „Pausatio“, ,Transitus", „Natale“, następnie zaś od końca VIII w. coraz częściej tytuł: „Assumptio“, t. j. „Wzięcie“ do nieba. Na równi z owymi tytułami wskazywały dawniejsze liturgie zachodnie (rzymska, gallikańska, mozarabska i in.), jako na główny przedmiot święta sierpniowego, na śmierć Marii i przejście Jej do chwały niebieskiej. Nie określały jednak wyraźnie, iż przejście to Najświętszej Panny, wzgl. Jej wzięcie do nieba dotyczyło nie tylko duszy, ale również ciała wskrzeszonego cudownie $z$ martwych zaraz po śmierci. Idee antycypowanego zmartwychwstania oraz cielesnego Wniebowzięcia były raczej tylko podsuwane dość silnie, a nie wyrażane jasno przez niektóre teksty

6) Jugie, dz. c., str. 58 .

7) O. Faller stara się wykazać (w dz. c. str. 18-26), że juz w V w. święto „Pamiątki Bożej Rodzicielki" było w Syrii i w ogóle na Wschodzie właściwym świętem Wniebowzięcia wzgl. Zaśnięcia Marii. Jednakże argumenty przytoczone na poparcie tej tezy nie są przekonywujące. 
mszalne owych liturgii. A jeśli chodzi o teksty brewiarzowe, to lekcje 2 nokturnu jutrzni, tak na samą uroczystość, jak również na wszystkie niemal dni oktawy, zawierały ustępy z Pseudo-Hieronimowego pisma „Ad Paulam et Eustochium“, w których autor wyraża pewną wątpliwość co do antycypowanego zmantwychwstania Marii oraz Jej cielesnego Wniebowzięcia. Również w prymie czytano przez dłuższy czas teksty podające w wątpliwość fakt Wniebowzięcia cielesnego, a mianowicie ustępy z martyrologiów Adona z Vienne, czy zwłaszcza Usuarda.

W nowszych czasach zaszły na Zachodzie pewne zmiany w liturgii Wniebowzięcia na skutek reformy ksiagg liturgicznych za pap. Piusa V oraz Klemensa VIII. Rezultatem owych zmian było wysunięcie na pierwszy plan, jako przedmiotu święta sierpniowego, faktu chwalebnego Wniebowzięcia Matki Bożej, zamiast, jak dotychczas faktu śmierci. Usunięto więc np. z formularza mszalnego kolektę ,Veneranda“, wskazującą na śmierć Marii, jako na bezpośredni przedmiot owego święta; a w modlitwie po komunii na wigilię Wniebowzięcia zmieniono słowa: ,....którzy obchodzimy odpocznienie świętej Bożej Rodzicielki" (...qui sanctae Dei Genitricis requiem celebramus...") na powiedzenie: ,,którzy uprzedzamy uroczystość świętej Bożej Rodzicielki“ bqui sanctae Dei Genitricis festivitatem praevenimus...") Z brewiarza zaś usunięto tak lekcje $\mathrm{z}$ pisma Pseudo-Hieronimowego, jak również ustępy z martyrologiów, wyrażające wątpliwość co do faktu Wniebowzięcia cielesnego. Na miejsce dawnych lekcji na sam dzień Wniebowzięcia wprowadzono najpierw za Piusa V ustęp z homilii, przypisywanej wówczas św. Atanazemu, w którym wyraźnie stwierdzony jest fakt Wniebowzięcia Marii co do duszy i ciała zarazem, a pominięta jest wzmianka o śmienci oraz zmartwychwstaniu. Następnie zaś za Klemensa VIII wymieniono i ów ustęp $\mathrm{z}$ homilii Pseudo-Atanazego na urywek $\mathrm{z}$ homilii św. Jana Damasceńskiego, mówiący również dosyć jasno o cielesnym Wniebowzięciu.

Jeśli chodzi o ostatecznie ustaloną liturgię rzymską sierpniowego święta, która obowiązuje dziś niemal w całym Kościele katolickim, to trzeba przyznać, że nie precyzuje ona całkiem jasno i dokładnie przedmiotu owego święta. Przynajmniej w najważniejszej części owej liturgii, t. j. we formularzu mszalnym, nie jest ów przedmiot całkiem dokładnie określony, choć wiadomo, że właśnie teksty mszalne (oczywiście owe zmienne) mają głównie za zadanie uwidaczniać charakter i treść danego święta.

Z formularza mszalnego na uroczystość Wniebowzięcia widać jasno, iż przedmiotem tej uroczyśstości jest chwalebne Wniebowzięcie 
Marii. Wskazuje na to już tekst wstępu (introitu): „Radujmy się wszyscy w Panu, obchodząc dzień uroczysty ku uczczeniu Błogosławionej Marii Dziewicy, z której Wniebowzięcia weselą się aniołowie i wychwalają Syna Bożego". Wskazują też słowa graduału i ofertorium: „. Wrięta jest Maria do nieba..." Wynika to również z prefacji wielbiącej Boga ,,we Wniebowzięciu (in Assumptione) Błogosławionej Marii zawsze Dziewicy" oraz z modlitwy po komunii, która mówi o obchodzeniu ze czcia Wniebowzięcia Boga Rodzicy (qui Assumptionem Dei Genitricis colimus..." ${ }^{8}$ ).

Ale natura Wniebowzięcia, które jako bezpośredni przedmiot święta sierpniowego uwidacznia się w tekstach mszalnych, nie jest w owych tekstach dość dokładnie sprecyzowana. Nie określają one bliżej, iż chodzi nie tylko o Wniebowzięcie co do duszy, ale również i co dc ciała. Wyraz ,Assumptio", choć podsuwa ideę cielesnego Wniebowzięcia i dlatego obecnie tylko w odniesieniu do Najśw. Marii Panny jest stosowany, nie domaga się jednak $z$ koniecznością takiego rozumienia. Wiadomo przecież, że wyrazem tym określano dawniej w Kościele także wyniesienie do chwały niebieskiej samej tylko duszy ${ }^{9}$ ).

Brak precyzji przy wskazywaniu przedmiotu święta uwlidacznia się również w tekstach brewiarzowych: antyfonach, responsoriach, wersetach. Mówią one także ogólnikowo tylko o chwalebnym Wniebowzięciu, jako przedmiocie święta, n. p.: ,Dziś Maria wstąpiła do nieba, cieszcie się, ponieważ króluje z Chrystusem na wieki"; albo: ,Wzięta jest Maria do nieba, radują się aniołowie..."; lub znowu: ,.Maria Panna wzięta jest do niebieskiego przybytku, w którym król królów zasiada na gwiaździstym tronie“; albo jeszcze: „Wyniesiona jest świẹta Boża Rodzicielka ponad chóry anielskie do królestwa niebieskiego" i t. p.

Szczegółowsze uwagi o charakterze Wniebowzięcia Marii, a również o sposobie zakończenia przez Nią życia ziemskiego, zawierają tylko lekcje 2-go nokturnu jutrzni na samą uroczystość Wniebowzięcia oraz na czwarty dzień w oktawie. Lekcje te, zawierające tylko urywki z homilii św. Jana Damásceńskiego częściowo autentyczne, częścią zaś interpolowane w IX wieku (należące do t. zw. ,historia euthymiaca“"), określają Wniebowzięcie Marii jako cielesne oraz podają opis śmierci

$\left.{ }^{8}\right)$ W kolekcie, w której zwykle wyraziściej, niż w innych tekstach mszalnych występuje przedmiot danego święta, nie ma żadnej aluzji do Wniebowzięcia; podobnie też w lekcji oraz ewangelii.

9) Tak np. św. Grzegorz Naz. mówi o Wniebowzięciu swej siostry Gorgonii, a św. Grzegorz z Tours o wniebowzięciu św. Awita. 
Jej w obecności apostołów, jak również otwarcia przez tych ostatnich pustego grobu Najśw. Panny w trzecim dniu po Jej pogrzebie. Z faktu włączenia do brewiarza tekstów ze stwierdzeniami cielesnego Wniebowzięcia Marii oraz Jej śmierci trzeba wnosić, że Kościół nie uważa owych twierdzeń za przeciwne wierze czy niebezpieczne dla niej, lecz owszem za idące po jej linii. Ale nie można sądzić, iż właśnie przez wspomniane lekcje 2-go nokturnu Kościół określił nieodwołalnie przedmiot święta Wniebowzięcia $\mathbf{w}$ sensie poprzedzonego śmiercią i zmartwychwstaniem wzięcia do nieba ciała Marii razem z duszą. Wiadomo bowiem, że lekcje 2-go nokturnu mają najmniejsze znaczenie, gdy chodzi o uwydatnianie treści doktrynalnej danego święta, wzgl. stwierdzanie i precyzowanie przez Kościół jakiegoś faktu dogmatyeznego. Nie są one weale do tego przeznaczone. Przez włączanie do oficjum brewiarzowego danych lekcji nie sankcjonuje Kościół jeszcze wszystkich twierdzeń w mich zawartych. Tym bardziej, że zdaje sobie przecież sprawę $\mathrm{z}$ tego, że niektóre opowiadania owych lekcji należą do legend. To też zdarza się usuwanie $\mathrm{z}$ brewiarza niektórych lekcji 2-go nokturnu i zastępowanie ich innymi, różniącymi się co do treści, jak właśnie stało się dwukrotnie z lekcjami na święto Wniebowzięcia, a postanowiona już była za Benedykta XIV trzecia zmiana, t. j. usunięcie ustępów z owej legendarnej ,historii eutymiackiej“, które czytamy w lekcjach na 4-ty dzień oktawy.

Mimo więc zawartych w lekcjach brewiarzowych na święto sierpniowe szczegółowych uwag odnośnie do natury Wniebowzięcia Marii oraz faktu i okoliczności Jej śmierci, można śmiało twierdzić, że Kościół nie określił dokładnie przedmiotu owego święta: wskazując w liturgii dzisiejszej Wniebowziẹcie Marii jako przedmiot, nie określił całkiem jasno, iż chodzi o Wniebowziẹcie nie tylko co do świẹtej duszy Boga Rodzicy, ale również co do ciała, o Wniebowzięcie ciała zmarłego najpierw, a następnie wskrzeszonego cudownie $z$ martwych.

A zatem, jak wskazują powyższe uwagi, liturgia sierpniowego święta maryjnego przechodziła - przynajmniej na Zachodzie - modyfikację, skutkiem których przedmiot bezpośredni tego święta niejednolicie się $w$ nicj wyrażał. Najpierw była nim (jak wynika już nawet z samych dawnych tyłułów: „Dormitio“, ezy „Depositio“, wzgl. „Pausatio“, lub ,Transitus“, lub „Natale“) święta śmierć Marii, jako mianowicie moment przejścia $z$ doczesności do chwały niebieskiej. Od wieku zaś IX-go, tak przez coraz powszechniejsze określanie święta w księgach liturgicznych mianem „Assumptio“, jak również przez modyfikację tekstów mszalnych i brewiarzowych. wskazane jest, jako 
bezpośredni przedmiot święta, chwalebne Wniebowzięcie Najśw. Panny. Ale Wniebowzięcie to nie jest co do swej natury całkiem dokładnie i jasno określone.

Wobec tego niesłuszną jest opinia, jakoby przez samю wprowadzenie powszechne święta sierpniowegó oraz jego liturgię stwierdzał Kościół oficjalnie, iż cielesne Wniebowzięcie Marii, wzgl. także Jej śmierć i antycypowane zmartwychwstanie, są faktalmi bezwzględnie pewnymi lub nawet faktami objawionymi przez Boga, stanowiącynni przedmiot wiary. Bo też Kościół nie chce angażować swego autorytetu nauczycielskiego przy zalecaniu czy wprowadzaniu święta opartego na jakimś fakcie, który mógłby nie należeć do objawienia, co do prawdziwości owego faktu czy jego objawionego charakteru. Wskazuje tylko przez wprowadzanie takiego święta, iż przyjmowanie faktu i kult z nim związany nie zagraża wierze oraz że kult taki jest odpowiednim. Dlatego też możliwa jest i faktycznie zdarza się w historii Kościoła zmiana tekstów liturgicznych i przedmiotu takich świąt, a nawet znoszenie miektórych $\mathrm{z}$ nich (np. święto przeniesienia domku loretańskiego zostało zniesione przez pap. Piusa X).

Ale oczywiście, choć nie można twierdzić, iż przez święto i liturgiẹ Wniebowzięcia Kościół poucza autorytatywnie wiernych o bezwzględnej prawdziwości faktu cielesnego Wniebowzięcia Matki Bożej, czy o należeniu tezy o cielesnym Wniebowzięciu do depozytu wiary, to jednak trzeba przyznać, że święto to posiada niemałe znaczenie dla sprawy dogmatyzacji Wniebowzięcia. Skierowywało ono bowiem umysły wiernych, a zwłaszcza teologów katolickich, ku kwestii sposobu zakończenia przez Marię życia doczesnego oraz losu dziewiczego Jej ciała, które wydało na świat Boga-Człowieka. Budziło to święto, będące wyrazem instynktownej wiary, pobożne przekonanie ogółu wiernych, świeckich i duchownych, o podsuwanym przez swa liturgię cielesnym Wniebowzięciu. Przyczyniło się tym samym do łatwiejszego wykrycia przez teologów racji, dla których uznali oni zgodnie, iż Wniebowzięcie Marlii z duszą i ciałem zarazem należy do faktów pewnych, a nawet objawionych i nadających się dlatego do dogmatyzacji.

Jeśli tedy nowa definicja mariologiczna dojdzie rychło do skutku (co wydaje się bardzo prawdopodobne), to będzie ona także w pewnym sensie wynikiem obchodzonego od wieków uroczyście święta Wniebowzięcia, zgodnie ze wspomnianą wyżej zasadą o stanowieniu przez kult normy dla wiary. 